\title{
Bt cotton influencing enzymatic activities under varied soils
}

\author{
Kasturikasen Beura ${ }^{1}$, Amitava Rakshit ${ }^{2^{*}}$ \\ ${ }^{1}$ Department of Soil Science and Agricultural Chemistry, Bihar Agricultural University, Sabour, Bihar, India \\ ${ }^{2}$ Department of Soil Science and Agricultural Chemistry, Banaras Hindu University, Varanasi, India; \\ *Corresponding Author: amitavabhu@gmail.com
}

Received 24 September 2013; revised 25 October 2013; accepted 30 October 2013

Copyright (C) 2013 Kasturikasen Beura, Amitava Rakshit. This is an open access article distributed under the Creative Commons Attribution License, which permits unrestricted use, distribution, and reproduction in any medium, provided the original work is properly cited.

\begin{abstract}
The enzymatic activity was evaluated under both Bt and non-Bt systems in varied soil type. The study was conducted during the 2010 wet season (July to December) in a net-house at the Institute of Agricultural Sciences of Banaras Hindu University. It was carried out on three different soil orders i.e. entisol, inceptisol and alfisol. Bt cotton (cvNCS-138) and its non-transgenic isoline (cvNCS-138) were grown until maturity. A no crop pot was maintained with three replications for all the three soil orders. Study design was a factorial experiment under a completely randomized block design with three replications. The study concludes that soil under Bt cotton cultivar produced significantly higher amount of phosphatase activity than both nonBt and no crop treatments at three growth stages. And the value decreased as the crop growth period advanced. The interaction effect between soil type and Bt-crop was found to be significant in different growth stages throughout the growing season. Results from the study revealed that a significant reduction (9.4\%) of the dehydrogenase activity and soil respiration (5\%) in the rhizosphere of $\mathrm{Bt}$ cotton over non-Bt isoline.
\end{abstract}

Keywords: Bt Cotton; Enzymatic Activity; Soil Orders

\section{INTRODUCTION}

Cotton (Gossypium hirsutum L.) is an important commercial crop in India and plays a significant role in the economy and sustainability. As an industrial crop, it sup- ports hundreds of millions of people through cultivation, processing, trading, transportation and marketing. India with 116.14 lakh hectares area producing 334 lakh bales is projected to replace China by 2020 [1]. This rise in production and productivity ( $>550 \mathrm{~kg} / \mathrm{ha})$ is mainly due to increasing yields, even though with slower yield growth than in the previous decade [2]. Genetically engineered plants to incorporate useful traits are a potential technology for the future development of sustainable cotton based agricultural systems in India. Transgenic cotton varieties modified to express the Cry1 Ac insecticidal toxin (Bt cotton) that is toxic to some insect pests is now grown worldwide. Through 1) the products of introduced genes, 2) modified rhizosphere chemistry, or 3) altered crop residue quality, genetically modified plants have the potential to significantly change microbial dynamics, soil biodiversity and essential ecosystem functions, such as nutrient mineralization, disease incidence, carbon turnover and plant growth. Cry1 $\mathrm{Ab}$ protein from biomass of Bt rice degraded faster in alkaline soil (halflife 11.5 d) than in acidic soil (half-life 34.3 d) [3]. However, there are few experimental data available, especially quantitative data, on the environmental conesquences of sustained expression and/or presence of $\mathrm{Bt}$ toxin in various parts of $\mathrm{Bt}$ cotton plants [4,5]. Given this, our research was designed to evaluate enzymatic activities under both Bt and non-Bt systems and varied soil type.

\section{MATERIALS AND METHODS}

\subsection{Experimental Site}

This experiment was conducted in the kharif season, 2010 (July to December ) under net house conditions on three different soil types at the Institute of Agricultural sciences, Banaras Hindu University, Varanasi $\left(25^{\circ} 19^{\prime} 60 \mathrm{~N}\right.$ Latitude and $83^{\circ} 0^{\prime} 0 \mathrm{E}$ Longitude). Bt cotton (cvNCS-138) 
and its non-transgenic isoline (cvNCS-138) were grown until maturity. A no crop pot was maintained with three replications for all the three soil types. The climate of Varanasi is semi-arid and sub-humid climate with moisture deficit index between 20 - 40, characterized by hot summers and cold winters. The soil (0 - $18 \mathrm{~cm}$ depth) used in this experiment was collected from the unfertilized and fallow for many years of of three orders i.e. entisol, inceptisol and alfisol from different geographical locations in the Varanasi and Mirjapur districts of Uttar Pradesh, India.

\subsection{Analysis of Soil}

The soil used in the pot experiment was air dried, ground and sieved through a $2 \mathrm{~mm}$ sieve, and then stored in plastic bags. The $\mathrm{pH}$ and electrical conductivity of soil was determined by 1:2 soil water suspensions [6], mechanical composition of the soil was determined by the hydrometer method [7], water holding capacity was determined by following [8] method, organic carbon content was determined by the wet oxidation method of [9], available $\mathrm{N}$ was determined by an alkaline potassium permanganate method [10], available phosphorus by $[11,12]$ method, available potassium was determined flamephotometrically by neutral $1 \mathrm{~N}$ ammonium acetate [6]. The DTPA-extractable $\mathrm{Zn}$ was determined according to the procedure outlined by [13] using atomic absorption spectrophotometer. Analysis of soil revealed that the red soil was silty clay loam in texture, where as black and alluvial soils were clayey and sandy loam respectively. Among the three soils, two were (black and alluvial soil) slightly alkaline and one (red soil) was acidic in reaction. All the soils have low organic matter content $\left(3.4-4.2 \mathrm{~g} \cdot \mathrm{kg}^{-1}\right)$ bulk density of soil varied from 1.38 $1.51 \mathrm{Mg} \cdot \mathrm{m}^{-3}$, EC varied from $0.32-0.61 \mathrm{dS} \cdot \mathrm{m}^{-1}, \mathrm{CEC}$ from 18.25 to $31.85 \mathrm{Cmol}(\mathrm{p}+) \mathrm{kg}^{-1}$, available $\mathrm{N}$ from 167 to $238 \mathrm{Kg} \cdot \mathrm{ha}^{-1}$, P from 8 to $18 \mathrm{Kg} \cdot \mathrm{ha}^{-1}$, $\mathrm{K}$ from 110 to $165 \mathrm{Kg} \cdot \mathrm{ha}^{-1}$, Ca from 3.1 to $32.5 \mathrm{meq} / 100 \mathrm{~g}$ and $\mathrm{Zn}$ from 2.86 to 3.84 ppm respectively.

Dehydrogenase activity was determined by monitoring the rate of triphenyl formazon (TPF) production from triphenyl tetrazolium chloride (TTC), using the spectrophotometer method [14]. For phosphatase enjyme, method proposed by [15] was used. $1 \mathrm{~g}$ of soil in a $50 \mathrm{~mL}$ Erlenmeyer flask with $0.2 \mathrm{~mL}$ toluene, $4 \mathrm{~mL}$ modified universal buffer and $1 \mathrm{~mL}$ p-nitrophenol phosphate solution will be allow for incubation at $37^{\circ} \mathrm{C}$ for $1 \mathrm{~h} .1 \mathrm{~mL}$ Calcium chloride and $4 \mathrm{~mL}$ sodium hydroxide will be added and the yellow colour intensity of the filtrate (i.e. p-nitrophenol) will be determined colorimetrically.

Soil respiration was estimated by measuring oxygen consumption by soil in a warburg flask incubated at $28^{\circ} \mathrm{C}$ $\pm 1^{\circ} \mathrm{C}$, as described by [16]. Soil samples for enjyme analysis were were estimated at regular time points throughout the growth stages of the plant.

\subsection{Statistical Analysis}

Data obtained from all the observation were statistically analysed, applying the factorial CRD. The least square difference (LSD) values were calculated to test the significance of treatment difference and LSD values were evaluated at 5\% level of significance by the following formula:

$$
\text { LSD or C.D. }=\sqrt{\frac{2 \mathrm{EMS}}{\mathrm{r}}} \times \mathrm{t} \text { at } 5 \% \propto
$$

$\therefore \mathrm{t}$ at $5 \% \propto=$ error degree of freedom at $5 \%$ level of significance $(\propto)$.

\section{RESULT AND DISCUSSION}

A transgenic Bt-cotton and its non-Bt counterpart were investigated to evaluate the potential risk of transgenes on the soil ecosystem. The activities of phosphatase and dehydrogenage in cotton rhizosphere were assayed during vegetative, reproductive and senescing stage (after harvest). Results showed that there were significant difference in enzymatic activities between $\mathrm{Bt}$ and non-Bt at any of the growth stages and after harvest.

From the Table 1 it has been observed that soil under Bt cotton cultivar produced significantly higher amount of phosphatase activity than both non-Bt and no crop treatments at three growth stages. And the value decreased as the crop growth period advanced. Among the three different soil types red soil produced lowest alkaline Phosphatase activity followed by alluvial soil and black soil Results in the study were in agreement with that by [17] who reported positive effect on acid phosphomonoesterase activity in soil amended with Bt-cotton plant materials. Alkaline phosphatase activity was higher than acid phosphatase activity, supporting similar observations on a typic Haplustept soil [18]. Phosphatase activity has been closely correlated with $\mathrm{pH}$. This is acid phosphatase predominate in acid soil and alkaline phosphatase activity in alkaline soil. In general, alkaline phosphatase is associated with microorganisms while the acid phosphatase is predominantly due to plants [19]. So, increase in microbial biomass might have attributed to the observed higher alkaline phosphatase activity. The interaction effect between soil type and Bt-crop was found to be significant in different growth stages throughout the growing season.

Dehydrogenase activity have potential to provide a unique index of general activity of soil microorganisms and integrative biological assessment pertaining to biological activity or biochemical processes of soils because of its relationship to soil biology. Dehydrogenase activity reflects the oxidative activity or intensity of metabolism 
Table 1. Phosphatase activity ( $\mu \mathrm{g}$ p-nitrophenol $\mathrm{g}^{-1}$ soil hour ${ }^{-1}$ ) in cotton rhizosphere soil at different growth stage.

\begin{tabular}{|c|c|c|c|c|c|}
\hline \multirow{2}{*}{ DAS } & \multirow{2}{*}{ Cultivar (C) } & \multicolumn{3}{|c|}{ Soil types (S) } & \multirow{2}{*}{ Mean } \\
\hline & & $\mathrm{S}_{1}$ & $\mathrm{~S}_{2}$ & $\mathrm{~S}_{3}$ & \\
\hline \multirow{5}{*}{0} & Non-Bt $\left(\mathrm{V}_{1}\right)$ & 167.33 & 187.63 & 185.93 & 180.29 \\
\hline & $\operatorname{Bt}\left(\mathrm{V}_{2}\right)$ & 158.43 & 175.7 & 175.33 & 169.82 \\
\hline & No crop $\left(\mathrm{V}_{3}\right)$ & 117.33 & 116.53 & 115.22 & 116.36 \\
\hline & Mean & 147.69 & 159.95 & 158.82 & \\
\hline & \multicolumn{5}{|c|}{$\begin{array}{l}\operatorname{LSD}(0.05) \mathrm{C}=0.53, \mathrm{~S}=0.53, \mathrm{CxS}=0.927 \\
\mathrm{SEm} \pm \mathrm{C}=0.178, \mathrm{~S}=0.178, \mathrm{CxS}=0.309\end{array}$} \\
\hline \multirow{5}{*}{100} & Non-Bt $\left(\mathrm{V}_{1}\right)$ & 164.53 & 166.13 & 164.13 & 164.93 \\
\hline & $\operatorname{Bt}\left(\mathrm{V}_{2}\right)$ & 169.4 & 183.4 & 181.5 & 178.1 \\
\hline & No crop $\left(\mathrm{V}_{3}\right)$ & 115.7 & 103.01 & 98.48 & 105.73 \\
\hline & Mean & 149.87 & 148.70 & 148.03 & \\
\hline & \multicolumn{5}{|c|}{$\begin{array}{l}\operatorname{LSD}(0.05) C=0.889, S=0.889, C x S=0.483 \\
\quad \operatorname{SEm} \pm C=0.29, S=0.29, C x S=0.161\end{array}$} \\
\hline \multirow{5}{*}{150} & Non-Bt $\left(\mathrm{V}_{1}\right)$ & 160.73 & 167.3 & 165.23 & 164.42 \\
\hline & $\operatorname{Bt}\left(\mathrm{V}_{2}\right)$ & 161.9 & 168.83 & 168.66 & 166.46 \\
\hline & No crop $\left(V_{3}\right)$ & 112.51 & 146.61 & 99.15 & 105.12 \\
\hline & Mean & 145.04 & 148.70 & 144.34 & \\
\hline & \multicolumn{5}{|c|}{$\begin{aligned} \operatorname{LSD}(0.05) C & =0.735, \mathrm{~S}=0.735, \mathrm{CxS}=0.513 \\
\mathrm{SEm} \pm \mathrm{C} & =0.27, \mathrm{~S}=0.27, \mathrm{CxS}=0.21\end{aligned}$} \\
\hline
\end{tabular}

$\mathrm{S}_{1}=$ Red soil, $\mathrm{S}_{2}=$ Black soil, $\mathrm{S}_{3}=$ Alluvial soil, $\mathrm{V}_{1}=$ Non-Bt cultivar, $\mathrm{V}_{2}=$ Bt cultivar, $\mathrm{V}_{3}=$ no crop, DAS $=$ Days after sowing.

of soil microflora and can be used as an indicator of microbial activity or populations in soils [20]. Results from the Table 2 revealed that a significant reduction $(9.4 \%)$ of the Dehydrogenase activity in the rhizosphere of Btcotton over non-Bt isoline. The lower dehydrogenase activity in rhizosphere soils under Bt-cotton is in conformity with the results of $[21,22]$. [23] also reported reduced dehydrogenase activity during the decomposition of straw from Bt-transgenic rice cultivars under flooded conditions in China. Lower dehydrogenase activity in the Bt-system indicates that a portion of the organisms was perhaps inhibited and did not participate in the metabolic activities of the soils [24]. It may have been partly because of unfavourable conditions in the rhizosphere under Bt-cotton or because of a negative effect of Bt-toxins on certain microbial groups, which might have retarded metabolic activities in the soil. However, [25] observed no differences in the dehydrogenase activity in the rhizosphere of Bt-cotton. The interaction effect between soil type and Bt-crop was found to be significant in different growth stages throughout the growing season.

From the Table 3 it has been observed that soil $\mathrm{CO}_{2}$ efflux generally decreased over time regardless of type of cotton; the highest soil $\mathrm{CO}_{2}$ efflux occurred during the
Table 2. Dehydrogenase activity ( $\mu \mathrm{g} \mathrm{TPF} \mathrm{h}^{-1} \cdot \mathrm{g}^{-1}$ soil) in cotton rhizosphere soil at different growth stage.

\begin{tabular}{|c|c|c|c|c|c|}
\hline \multirow{2}{*}{ DAS } & \multirow{2}{*}{ Cultivar (C) } & \multicolumn{3}{|c|}{ Soil types (S) } & \multirow{2}{*}{ Mean } \\
\hline & & $\mathrm{S}_{1}$ & $\mathrm{~S}_{2}$ & $\mathrm{~S}_{3}$ & \\
\hline \multirow{5}{*}{50} & Non-Bt $\left(\mathrm{V}_{1}\right)$ & 20.7 & 31.4 & 35.4 & 29.16 \\
\hline & $\operatorname{Bt}\left(\mathrm{V}_{2}\right)$ & 19.33 & 29.86 & 33.6 & 27.59 \\
\hline & No crop $\left(\mathrm{V}_{3}\right)$ & 14.07 & 20.41 & 21.24 & \multirow[t]{2}{*}{18.57} \\
\hline & Mean & 18.03 & 27.22 & 30.08 & \\
\hline & \multicolumn{5}{|c|}{$\begin{array}{l}\operatorname{LSD}(0.05) \mathrm{C}=0.211, \mathrm{~S}=0.211, \mathrm{CxS}=0.263 \\
\quad \mathrm{SEm} \pm \mathrm{C}=0.069, \mathrm{~S}=0.069, \mathrm{CxS}=0.083\end{array}$} \\
\hline \multirow{5}{*}{100} & Non-Bt $\left(\mathrm{V}_{1}\right)$ & 22.4 & 36.2 & 41.46 & 33.35 \\
\hline & $\mathrm{Bt}\left(\mathrm{V}_{2}\right)$ & 21.73 & 31 & 34.2 & 28.97 \\
\hline & No crop $\left(\mathrm{V}_{3}\right)$ & 15.23 & 23.53 & 24.82 & \multirow[t]{2}{*}{21.19} \\
\hline & Mean & 19.78 & 30.24 & 33.49 & \\
\hline & \multicolumn{5}{|c|}{$\begin{array}{c}\operatorname{LSD}(0.05) \mathrm{C}=0.321, \mathrm{~S}=0.321, \mathrm{CxS}=0.483 \\
\mathrm{SEm} \pm \mathrm{C}=0.064, \mathrm{~S}=0.064, \mathrm{CxS}=0.161\end{array}$} \\
\hline \multirow{5}{*}{150} & Non-Bt $\left(\mathrm{V}_{1}\right)$ & 21.73 & 26.26 & 24.56 & 24.18 \\
\hline & $\operatorname{Bt}\left(V_{2}\right)$ & 20.86 & 25.6 & 23.43 & 23.29 \\
\hline & No crop $\left(\mathrm{V}_{3}\right)$ & 14.77 & 17.06 & 14.73 & \multirow[t]{2}{*}{15.52} \\
\hline & Mean & 19.12 & 22.97 & 20.90 & \\
\hline & \multicolumn{5}{|c|}{$\begin{array}{c}\operatorname{LSD}(0.05) \mathrm{C}=0.222, \mathrm{~S}=0.222, \mathrm{CxS}=0.385 \\
\quad \mathrm{SEm} \pm \mathrm{C}=0.07, \mathrm{~S}=0.07, \mathrm{CxS}=0.122\end{array}$} \\
\hline
\end{tabular}

$\mathrm{S}_{1}=$ Red soil, $\mathrm{S}_{2}=$ Black soil, $\mathrm{S}_{3}=$ Alluvial soil, $\mathrm{V}_{1}=$ Non-Bt cultivar, $\mathrm{V}_{2}=$ Bt cultivar, $\mathrm{V}_{3}=$ no crop, DAS $=$ Days after sowing.

first 6 weeks of crop growth. Soil $\mathrm{CO}_{2}$ efflux from control was significantly lower than that of the Bt-cotton and non-Bt isoline soils only during the first month; $\mathrm{CO}_{2}$ efflux from Bt-cotton and non-Bt isoline soils did not differ, regardless of varied soil type. Further it was also noticed that non-Bt isoline crop produced significantly higher amount of $\mathrm{CO}_{2}$ evolution than both $\mathrm{Bt}$ cotton crop and no crop treatments at three soil sampling dates. Lower amount of $\mathrm{CO}_{2}$ evolution in $\mathrm{Bt}$ cotton soil due to high $\mathrm{C}: \mathrm{N}$ ratio of $\mathrm{Bt}$ cotton compare to non $\mathrm{Bt}$ cotton. The Bt crop, including root, stem and leaves had higher lignin, lignin/ $\mathrm{N}$ ratio and total organic $\mathrm{C}$ contents than those of non-Bt crop. Among soils, $\mathrm{CO}_{2}$ evolution is lowest in red soil as compared to black and alluvial soil. Efflux of $\mathrm{CO}_{2}$ from red soil was about $25 \%$ less than observed from alluvial soil. No significant interactions among the treatments were observed.

\section{CONCLUSION}

A critical persual of the experiment revealed that soil under Bt cotton cultivar produced significantly higher amount of phosphatase activity than both non-Bt and no crop treatments at three growth stages. And the value decreased as the crop growth period advanced. The in- 
Table 3. Carbon dioxide evolution $\left(\mathrm{mg} \mathrm{CO}_{2}-\mathrm{c} / 100 \mathrm{~g}\right.$ soil) in cotton rhizosphere soil at different growth stage.

\begin{tabular}{|c|c|c|c|c|c|}
\hline \multirow{2}{*}{ DAS } & \multirow{2}{*}{ Cultivar (C) } & \multicolumn{3}{|c|}{ Soil types (S) } & \multirow{2}{*}{ Mean } \\
\hline & & $\mathrm{S}_{1}$ & $\mathrm{~S}_{2}$ & $\mathrm{~S}_{3}$ & \\
\hline \multirow{5}{*}{50} & Non-Bt $\left(\mathrm{V}_{1}\right)$ & 31.53 & 44.3 & 53.43 & 29.16 \\
\hline & $\mathrm{Bt}\left(\mathrm{V}_{2}\right)$ & 27.90 & 41.43 & 48.57 & 27.59 \\
\hline & No crop $\left(V_{3}\right)$ & 23.13 & 35.87 & 42.50 & 18.57 \\
\hline & Mean & 27.52 & 40.53 & 48.16 & \\
\hline & \multicolumn{5}{|c|}{$\begin{array}{c}\mathrm{LSD}(0.01) \mathrm{C}=4.83, \mathrm{~S}=4.83, \mathrm{CxS}=8.36 \\
\mathrm{SEm} \pm \mathrm{C}=1.19, \mathrm{~S}=1.19, \mathrm{CxS}=2.05\end{array}$} \\
\hline \multirow{5}{*}{100} & Non-Bt $\left(\mathrm{V}_{1}\right)$ & 21.10 & 29.93 & 39.83 & 30.28 \\
\hline & $\mathrm{Bt}\left(\mathrm{V}_{2}\right)$ & 19.10 & 25.67 & 35.13 & 6.63 \\
\hline & No crop $\left(V_{3}\right)$ & 12.13 & 21.47 & 29.27 & 20.95 \\
\hline & Mean & 17.44 & 25.69 & 34.74 & \\
\hline & \multicolumn{5}{|c|}{$\begin{array}{c}\operatorname{LSD}(0.01) \mathrm{C}=4.52, \mathrm{~S}=4.52, \mathrm{CxS}=7.83 \\
\mathrm{SEm} \pm \mathrm{C}=1.11, \mathrm{~S}=1.11, \mathrm{CxS}=1.92\end{array}$} \\
\hline \multirow{5}{*}{150} & Non-Bt $\left(\mathrm{V}_{1}\right)$ & 11.13 & 15.67 & 20.20 & 15.66 \\
\hline & $\operatorname{Bt}\left(\mathrm{V}_{2}\right)$ & 9.50 & 13.87 & 17.37 & 13.58 \\
\hline & No crop $\left(V_{3}\right)$ & 7.03 & 12.67 & 14.27 & 11.32 \\
\hline & Mean & 9.22 & 14.07 & 17.28 & \\
\hline & $\begin{array}{r}\mathrm{LSD}(0 . \\
\text { SEm }\end{array}$ & $\begin{array}{l}\mathrm{C}=3.2 \\
=0.79,\end{array}$ & $\begin{array}{l}=3.2 \\
0.79\end{array}$ & $\begin{array}{l}\mathrm{xS}=5.59 \\
=1.37\end{array}$ & \\
\hline
\end{tabular}

$\mathrm{S}_{1}=$ Red soil, $\mathrm{S}_{2}=$ Black soil, $\mathrm{S}_{3}=$ Alluvial soil, $\mathrm{V}_{1}=$ Non-Bt cultivar, $\mathrm{V}_{2}=$ Bt cultivar, $\mathrm{V}_{3}=$ no crop, DAS $=$ Days after sowing.

teraction effect between soil type and Bt-crop was found to be significant in different growth stages throughout the growing season. Results from the study revealed that a significant reduction $(9.4 \%)$ of the dehydrogenase activity soil respiration $(5 \%)$ in the rhizosphere of Bt-cotton over non-Bt isoline. The above results suggest that Btcotton may constrain the availability of $\mathrm{N}$, but enhances p-availability in these soils.

\section{REFERENCES}

[1] Qaim, M. and Zilberman, D. (2003) Yield effects of genetically modified crops in developing countries. Science, 299, 900-902. http://dx.doi.org/10.1126/science.1080609

[2] http://cotcorp.gov.in/national-cotton.aspx

[3] Wang, H., Ye, Q., Wang, W., Wu L. and Wu, W. (2006) $\mathrm{Cry} 1 \mathrm{Ab}$ protein from $\mathrm{Bt}$ transgenic rice does not residue in rhizosphere soil. Environmental Pollution, 143, 449455. http://dx.doi.org/10.1016/j.envpol.2005.12.006

[4] Beura, K. and Rakshit, A. (2011) Effect of Bt cotton on nutrient dynamics under varied soil type. Italian Journal of Agronomy, 6, 25-28. http://dx.doi.org/10.4081/ija.2011.e35

[5] Beura, K. and Rakshit, A. (2012) Effect of BT Cotton on Arbuscular mycorrhizal fungiinfection under varied soil type. Mycorrhiza News, 24, 11-12.

[6] Jackson, M.L. (1973) Soil chemical analysis. 1st Edition, Prentice Hall of India Pvt. Ltd., New Delhi.

[7] Bouyoucos, G.J. (1962) Hydrometer method improved for making particle size analysis of soils. Agronomy Journal, 54, 464-465.

http://dx.doi.org/10.2134/agronj1962.0002196200540005 $\underline{0028 \mathrm{x}}$

[8] Topp, G.C., Galganov, Y.T., Ball, B.C. and Carter, M.R. (1993) Soil water desorption curves. In: Carter, M.R., Ed., Soil Sampling and Methods of Analysis, Canadian Society of Soil Science, Lewis Publishers, Boca Raton.

[9] Walkley, A. and Black, I.A. (1934) An examination of the degtjareff method for determining soil organic matter and a proposed modification of the chromic acid titration method. Soil Science, 37, 29-38. http://dx.doi.org/10.1097/00010694-193401000-00003

[10] Subbiah, B.V. and Asija, G.L. (1956) A rapid procedure for determination of available nitrogen in soils. Current Science, 31, 259-260.

[11] Bray, R.H. and Kurtz, L.T. (1945) Determination of total, organic and available forms of phosphorus in soils. Soil Science, 59, 39-46. http://dx.doi.org/10.1097/00010694-194501000-00006

[12] Olsen, S.R., Cole, C.V., Watamable, F.S. and Dean, L.A. (1954). Estimation of available phosphorus in soil by extraction with sodium bicarbonate. US Department Agriculture Circular, 939, 1-19.

[13] Lindsay, W.L. and Norvell, W.A. (1978) Development of a DTPA soil test for zinc, iron, manganese and copper. Soil Science Society America Journal, 42, 421-428. http://dx.doi.org/10.2136/sssaj1978.03615995004200030 $\underline{009 x}$

[14] Klein, D.A., Loh, T.C. and Goulding, R.L. (1971) A rapid procedure to evaluate dehydrogenase activity of soils low in organic matter. Soil Biology Biochemistry, 3, 385-387. http://dx.doi.org/10.1016/0038-0717(71)90049-6

[15] Tabatabai, M.A. and Bremner, J.M. (1969) Use of p-nitrophenol phosphate for the assay of soil phosphatase activity. Soil Biology Biochemistry, 1, 301-307. http://dx.doi.org/10.1016/0038-0717(69)90012-1

[16] Umbreit, W.W., Burris, R.H. and Stouffer, J.F. (1972) Manometric and biochemical techniques-A manual describing methods applicable to the study of tissue metabolism. 5th Edition, Burgers Pub. Co., Sudbury.

[17] Sun, C.X., Chen, L.J., Wu, Z.J., Zhou, L.K. and Shimizu, H. (2007) Soil persistence of $<i>$ Bacillus thuringiensis $</ \mathrm{i}>(\mathrm{Bt})$ toxin from transgenic $\mathrm{Bt}$ cotton tissues and its effect on soil enzyme activities. Biology Fertility Soils, 43, 617-620. http://dx.doi.org/10.1007/s00374-006-0158-6

[18] Mandal, A., Patra, A.K., Singh, D., Swarup, A. and Mastro, R.E. (2007) Effect of long term application of manure and fertilizer on biological and biochemical activities in soil during crop development stage. Bioresource Technology, 98, 3585-3592. http://dx.doi.org/10.1016/j.biortech.2006.11.027

[19] Tarafdar, J.C. and Claassen, N. (1988) Organic phosphorrus compounds as a phosphorus source for higher plants 
through the activity of phosphatases produced by plant roots and microorganisms. Biology Fertility Soils, 5, 308312. http://dx.doi.org/10.1007/BF00262137

[20] Nannipieri, P., Grego, S. and Ceccanti, B. (1990) Ecological significance of the biological activity in soil. In: Bollag, J.M. and Stotzky, G., Eds., Soil Biochemistry (Vol. 6), Marcel Dekker, New York, 293-355.

[21] Wu, W.-X., Ye, Q.-F., Min, H.G., Duan, X.-J. and Jin, W.M. (2004) Bt-transgenic rice straw affects the culturable microbiota and dehydrogenase and phosphatase activities in a flooded paddy soil. Soil Biology Biochemistry, 36, 289-295.

http://dx.doi.org/10.1016/j.soilbio.2003.09.014

[22] Donegan, K.K., Schaller, D.L., Stone, J.K., Ganio, L.M., Reed, G., Hamm, P.B. and Seidler, R.J. (1996) Microbial populations, fungal species diversity and plant pathogen levels in field plots of potato plants expressing the Bacillus thuringiensis var. Tenebrionis endotoxin. Transgenic Research, 5, 25-35.
http://dx.doi.org/10.1007/BF01979919

[23] Sarkar, B., Patra A.K. and Purakayastha, T.J. (2008) Transgenic Bt-cotton affects enzyme activity and nutrient availability in a sub-tropical Inceptisol. Journal of Agronomy Crop Science, 194, 289-296. http://dx.doi.org/10.1111/j.1439-037X.2008.00312.x

[24] Masto, R.E., Chhonkar, P.K., Singh, D. and Patra, A.K. (2006) Changes in soil biological and biochemical characteristics in a long-term field trial on a sub-tropical inceptisol. Soil Biology Biochemistry, 38, 1577-1582. http://dx.doi.org/10.1016/j.soilbio.2005.11.012

[25] Shen, R.F., Cai, H. and Gong, W.H. (2006) Transgenic Bt cotton has no apparent effect on enzymatic activities or functional diversity of microbial communities in rhizosphere soil. Plant Soil, 285, 149-159.

http://dx.doi.org/10.1007/s11104-006-9000-z 